\title{
ANALISA PENGEPRESAN DENGAN SISTEM HIDROLIK PADA ALAT PEMBUAT PAVING BLOCK UNTUK PERKERASAN LAHAN PARKIR
}

\author{
Untung Surya Dharma ${ }^{1, a}$, Lukito Dwiyuono ${ }^{2, b}$ \\ 1,2 Program Studi Teknik Mesin, Fakultas Teknik, Univ. Muhammadiyah Metro \\ Jl. Ki Hajar Dewantara 15 A Metro, Lampung \\ a untungsdh@yahoo.co.id \\ blukito@yahoo.co.id
}

\begin{abstract}
Abstrak
Paving block adalah salah satu bagian dari bahan bangunan yang banyak digunakan sebagai bahan perkerasan baik untuk jalan, trotoar maupun lahan parkir. Namu dipasaran mutu paving blok yang ada sangat rendah, sehingga cepat retak dan patah. Hal ini dikarenakan berbagai faktor antara lain komposisi campuran bahan dan proses pembuatan yang kurang tepat. Untuk mengatasi hal tersebut agar menghasilkan paving blok bermutu sesuai standar SNI 0306911996 maka diperlukan mesin pembuat paving blok dengan proses pengepresan menggunakan sistem hidroulik. tujuan dari penelitian ini adalah untuk mendapatkan desain dan alat pembuat paving block yang dapat digunakan membuat paving blok memenuhi syarat standar SNI 0306911996 untuk perkerasan lahan parkir dengan tekanan pengepresan maksimal. Metode yang digunakan adalah metode eksperimental untuk menganalisa kekuatan cetakan paving block, menghitung gaya saat penekanan pada cetakan, menghitung tegangan lentur yang diizinkan serta yang terjadi dan melakukan pengujian kuat tekan paving block yang dilakukan dilaboratorium kampus 2 fakultas teknik universitas muhammadiyah metro. Adapun hasil penelitian pada cetakan paving block dan pengujian kuat tekan paving yaitu dari hasil analisa kekuatan cetakan terhadap pengaruh tekanan di dapat gaya pada variasi 2 cetakan sebesar $58663,8 \mathrm{~N}$, variasi 3 cetakan 81619,2 $\mathrm{N}$, dan variasi 4 cetakan $113501,7 \mathrm{~N}$. Untuk tegangan lentur yang diizinkan di dapat nilai sebesar $30247500 \mathrm{~N} / \mathrm{m}^{2}$. Untuk tegangan lentur yang terjadi didapat untuk variasi 2 cetakan sebesar $1629550 \mathrm{~N} / \mathrm{m}^{2}$ untuk panjang plat, sedangkan untuk lebar sebesar $2444325 \mathrm{~N} / \mathrm{m}^{2}$, untuk variasi 3 cetakan sebesar $2040480 \mathrm{~N} / \mathrm{m}^{2}$ untuk panjang plat, sedangkan untuk lebar sebesar $2720640 \mathrm{~N} / \mathrm{m}^{2}$, untuk variasi 4 cetakan sebesar $1891695 \mathrm{~N} / \mathrm{m}^{2}$ untuk panjang plat, sedangkan untuk lebar sebesar $3783390 \mathrm{~N} / \mathrm{m}^{2}$. Dari hasil pengujian kuat tekan paving block didapatkan nilai rata-rata perbandingan untuk setiap variasi cetakan didapat $8,375 \mathrm{MPa}$ untuk variasi 2 cetakan, 7,525 MPa untuk variasi 3 cetakan dan 5,1041667 MPa untuk variasi 4 cetakan. Bila melihat hasil rata-rata pada grafik diatas sesuai SNI nilai yang didapat utuk paving block pada variasi 2 cetakan termasuk dalam mutu untuk taman.
\end{abstract}

Kata Kunci : Analisa Cetakan, Paving Block, Kuat Tekan, Standar SNI.

\section{Pendahuluan}

Paving block adalah salah satu bagian dari bahan bangunan yang banyak digunakan sebagai bahan perkerasan baik untuk jalan, trotoar maupun lahan parkir. Perkerasan kaku paving blok ini dengan menggunakan campuran beton bertulang atau mengunakan balok beton terkunci.
Beberapa kenyataan yang ada dipasaran, mutu paving blok yang ada cepat retak dan patah karena paving blok bersifat getas. Hal ini bisa jadi disebabkan oleh mutu bahan yang tidak memenuhi syarat, komposisi bahan yang tidak memenuhi standart, gerusan air hujan, beban-beban kejut akibat lintasan roda 
kendaraan, kurangnya penambahan pressing pada saat proses pembuatan paving blok dan lain-lain. Menurut hasil penelitian, sistem pencetakan tetap diharapkan mampu menjamin keseragaman mutu hasil cetakan. Hasil pengujian kuat tekan tekan sampel bata beton, diperoleh angka perbandingan antara sistem manual dengan sistem semimekanis yang menunjukkan peningkatan antara 178,23\% (komposisi semen dan pasir $1: 5$ ) dan $163,9 \%$ (komposisi semen dan pasir 1 : 4). Sedangkan hasil pengujian keausan nilai hasil dapat dikategorikan kelas II (SNI, nilai aus < 0,130).

Untuk mengatasi masalah tersebut, perlu dibuat sebuah mesin produksi paving block yang bisa menghasilkan paving dengan standart yang sama dalam hal proses penekanannya. Untuk memperkecil biaya produksi, rancangan mesin press tersebut tidak harus menggunakan bahanbahan terbaik, tetapi lebih dititik tekankan pada hasil penekanan (pengepresan) yang bisa menghasilkan paving block dengan mutu yang bisa memenuhi standart SNI 0306911996.

Dari penjelelasan diatas maka penulis bermaksud untuk menganalisa sistem pengepresan dengan menggunakan sistem hidroulik pada alat pembuat paving blok yang nantinya dapat digunakan sebagai perkerasan lahan parkir.

\section{Tinjauan Teoritis}

Paving block atau bata beton adalah suatu komponen bahan bangunan yang dibuat dari campuran semen hidrolis atau sejenisnya, agregat dan air dengan atau tanpa bahan tambahan lainnya yang tidak mengurangi mutu paving block tersebut.

Paving block dapat diproduksi secara mekanis, semi mekanis, atau dengan cetak tangan. Pada umumnya paving block yang diproduksi dengan peralatan mekanis memiliki mutu yang lebih tinggi daripada dengan cara lainnya. Bahan-bahan dicampur dalam perbandingan tertentu sesuai dengan peruntukan dan mutu yang direncanakan, kemudian dicetak dan dipadatkan dengan mesin getar, lalu disimpan pada tempat yang terlindung dari panas matahari langsung serta dari hembusan angin yang berlebihan. Paving block yang digunakan untuk jalan setapak, pertamanan dan lain-lain yang tidak menerima beban berat dapat menggunakan mutu kelas III, dengan perbandingan campuran 1 bagian berat semen dengan 5 bagian berat pasir, dengan cara konvensional (penekanan $\pm 20 \mathrm{~kg} / \mathrm{cm} 2$ ) . Untuk menjaga agar lebih tahan terhadap keausan dapat diberi lapisan kepala setebal $1 \mathrm{~cm}$ dengan perbandingan campuran 1 bagian berat semen dengan 3 bagian berat pasir dan faktor air semen yang digunakan berkisar antara 0,3-0,4.

Kuat tekan paving block merupakan salah satu parameter kualitas mutu yang harus diperhatikan selain ketahanan aus dan daya serap air. Kuat tekan paving block sangat dipengaruhi oleh perbandingan bahan penyusunnya. Menurut SNI 03-1974-1990 kuat tekan beton adalah besarnya beban per satuan luas, yang menyebabkan benda uji hancur bila dibebani dengan gaya tekan tertentu yang dihasilkan oleh mesin tekan.

Persyaratan paving block di indonesia diatur dalam SNI 03-06911996 mengacu pada peraturan tersebut [1], mutu paving block diklasifikasikan menjadi :
a. Mutu A : untuk jalan
b. Mutu B : untuk pelataran parkir
c. Mutu C : untuk pejalan kaki
d. Mutu D: untuk taman. 
Tabel 1. Kekuatan fisik paving block SNI 03-0691-1996[1]

\begin{tabular}{|l|l|c|c|}
\hline No & Material & $\begin{array}{c}\text { Max. Load } \\
\text { Kgf }\end{array}$ & $\begin{array}{c}\text { Kuat Tekan } \\
\mathrm{kgffm}^{2}\end{array}$ \\
\hline 1 & Mesin pres Hidrolik $(\mathrm{A})$ & 14771,1 & 73,85 \\
\hline \multirow{2}{*}{2} & Mesin pres pneumatik $\left(\mathrm{B}_{1}\right)$ & 5908,4 & 29,54 \\
\cline { 2 - 4 } & Mesin pres pneumatik $\left(\mathrm{B}_{2}\right)$ & 5806,8 & 29,03 \\
\cline { 2 - 4 } & Mesin pres pneumatik $\left(\mathrm{B}_{3}\right)$ & 6203,0 & 31,01 \\
\hline
\end{tabular}

Untuk pengujian pada kuat tekan paving blok maka di tentukan perhitungan dasar sebagai berikut [2]:

$$
\tau=\mathrm{F} / \mathrm{A}
$$

Dengan :

$$
\begin{aligned}
& \tau=\text { Kuat tekan }\left(\mathrm{N} / \mathrm{cm}^{2}\right) \\
& \mathrm{F}=\text { Beban maksimum }(\mathrm{N}) \\
& \mathrm{A}=\text { Luas Bidang Permukaan }\left(\mathrm{cm}^{2}\right)
\end{aligned}
$$

Proses pengujian yang pernah dilakukan dengan menggunakan material berupa pasir, pecahan batu/abu batu, semen dan cairan perekat beton. Komposisi paduan meliputi pasir: $3 \mathrm{~kg}$, abu batu $3 \mathrm{~kg}$, semen $1 \mathrm{~kg}$ dan 5 sendok cairan perekat beton yang dicampur dengan air. Komposisi diatas untuk membuat dimensi paving block dengan volume $20 \times 10 \times 6 \mathrm{~cm}$. Tekanan yang digunakan untuk menekan adonan paving pada sistem pneumatik ini sebesar $128 \mathrm{~kg}$. Diketahui bahwa kekuatan tekan paving block juga sangat dipengaruhi oleh waktu penahanan setelah dicetak. Waktu penahanan berkisar 25-30 hari untuk mendapatkan kekerasan paving block yang maksimal. Sample uji dilakukan penahanan selama 12 hari sebelum dilakukan pengujian kuat tekan. Pengujian dilakukan dengan mesin universal testing GOTECH -GT-7001-LC30.

\begin{tabular}{|c|c|c|c|c|c|}
\hline \multirow[t]{2}{*}{ Mutu } & \multicolumn{2}{|c|}{$\begin{array}{c}\text { KLai tokall } \\
\text { (MPa) }\end{array}$} & \multicolumn{2}{|c|}{$\begin{array}{l}\text { Ketahaian at's } \\
\text { (mm/menit) }\end{array}$} & \multirow{2}{*}{$\begin{array}{c}\begin{array}{c}\text { Penyerapan } \\
\text { air rata-rata maks }\end{array} \\
(\%)\end{array}$} \\
\hline & Rata-rata & Min. & Rate-vata & Min. & \\
\hline A & 40 & 35 & 0,090 & 0,103 & 3 \\
\hline B & 20 & 17,0 & 0,130 & 0,149 & 6 \\
\hline C & 15 & 12,5 & 0,160 & 0,184 & 8 \\
\hline D & 10 & 8,5 & 0,219 & 0,251 & 10 \\
\hline
\end{tabular}
Adapun hasil pengujian sebagaimana ditunjukkan pada Tabel 2 [3].
Tabel 2. Uji Tekan Paving Block

Dari Tabel 2 diatas dapat dijelaskan bahwa rata-rata kuat tekan paving block hasil press dengan sistem pneumatik menunjukkan nilai lebih rendah sebesar $40 \%$ jika dibandingkan dengan paving block hasil press sistem hidrolik. Sedangkan rata-rata kuat tekan sebesar 29,86 Kgf $/ \mathrm{cm}^{2}$. Beban maksimal merupakan besarnya gaya tekan yang mampu diterima oleh paving block sampai pecah rata-rata sebesar 5972,73 Kgf. Sedangkan kuat tekan merupakan nilai bagi antara beban maksimal $(\mathrm{Kg})$ dengan luas paving yang ditekan $\left(\mathrm{cm}^{2}\right)$.

\section{Alat Pembuat paving block dengan} Metode Mekanis

Proses pembuatan paving block dengan menggunakan mesin paving relatif sangan mudah sekali berbeda jika pembuatan paving block dilakukan secara manual, dimana sangat membutuhkan waktu yang lama dan pengukuran ketebalan paving blocknya pun tidak dapat sama merata di setiap paving block yang sudah tercetak (gambar 1). Hal ini dapat mengakibatkan hasil yang didapat ketika di gunakan untuk pengeras tidak memuaskan. 


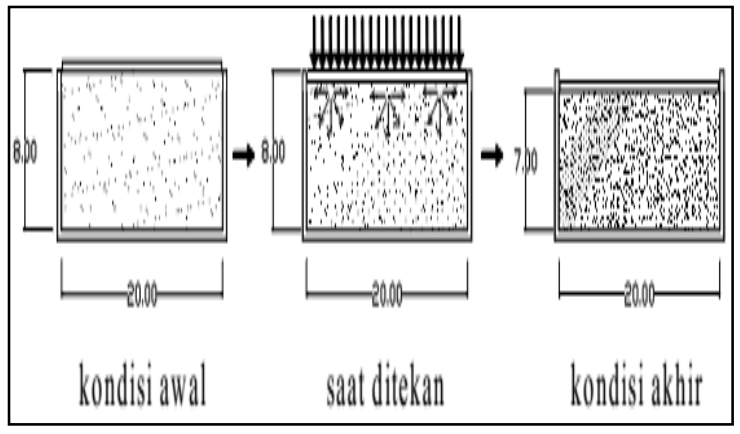

Sumber : http :

//www.google.co.id/search?q=prinsip+kerja+alatpaving+mekani s.com

\section{Gambar 1. Prinsip Kerja Metode Mekanis [4]}

Mesin cetak paving block berfungsi sebagai pengepres campuran bahan menjadi paving block. Mesin ini menggunakan sistem tenaga hidrolik. Pembuatan paving block dengan alat ini akan lebih cepat, menghemat waktu dan biaya sehingga dapat meningkatkan hasil produksi paving block dengan menggunakan mesin cetak paving block (Gambar 2).

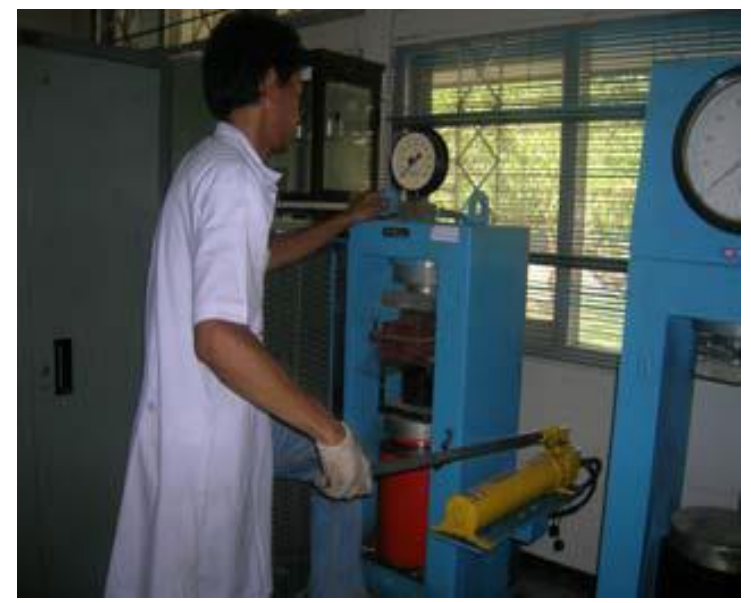

Sumber : http :

/www.google.co.id/search?q=prinsip+kerja+alatpaving+mekanis .com

Gambar 2. Alat cetak paving block [5]

Dalam penelitian untuk mengembangkan prototip alat cetak paving block semi mekanis. Desain alat tersebut bersifat semi mekanis, dirancang dengan menggunakan tenaga hidrolik dan dilengkapi pula dengan pegas otomatis sehingga dapat kembali ke posisi semula.
Untuk proses pemadatan, tekanan hidrolik yang dihasilkan berkisar hingga 1ton.

Hasil simulasi dilaboratorium menunjukkan kecepatan produksi meningkat hingga 2 kali lipat bila dibandingkan sistem tekan manual (dipukul). Selain itu dengan sistem pencetakan yang tetap diharapkan mampu menjamin keseragaman mutu hasil cetakan. Hasil pengujian kuat tekan tekan sampel bata beton, diperoleh angka perbandingan antara sistem manual dengan sistem semi-mekanis yang menunjukkan peningkatan antara 178,23\% (komposisi semen dan pasir $1: 5)$ dan 163,9\% (komposisi semen dan pasir 1 : 4). Sedangkan hasil pengujian keausan nilai hasil dapat dikategorikan kelas II (SNI, nilai aus < 0,130) [6].

\section{Sistem Hidrolik}

Sistem hidrolik adalah sistem penerusan daya dengan menggunakan fluida cair. Prinsip dasar dari sistem hidrolik adalah memanfaatkan sifat bahwa zat cair tidak mempunyai bentuk yang tetap, namun menyesuaikan dengan yang ditempatinya. Zat cair bersifat inkompresibel. Karena itu tekanan yang diterima diteruskan ke segala arah secara merata.

Sistem hidrolik biasanya diaplikasikan untuk memperoleh gaya yang lebih besar dari gaya awal yang dikeluarkan. Fluida penghantar ini dinaikkan tekanannya oleh pompa yang kemudian diteruskan ke silinder kerja melalui pipa-pipa saluran dan katup-katup. Gerakan translasi batang piston dari silinder kerja yang diakibatkan oleh tekanan fluida pada ruang silinder dimanfaatkan untuk gerak maju dan mundur maupun naik dan turun sesuai dengan pemasangan silinder yaitu arah horizontal maupun vertikal.

Analisa pada sistem hidrolik berkaitan erat dengan gaya - gaya yang timbul akibat penekanan, yaitu meliputi gaya - gaya tekanan pada mesin dalam 
sistem hidroliknya. Dalam hukum pascal, tekanan yang diberikan pada zat cair atau hidrolik dalam bejana tertutup, besarnya tekanan akan diteruskan ke segala arah dengan tekanan sama besar, Keberadaan gaya-gaya yang mempengaruhi sistem menjadi suatu obyek tinjauan utama. Sedangkan dalam perhitungan sistem hidrolik dan dasar ny, gaya-gaya yang diperhitungkan adalah tekanan pada mesin, massa zat dan kuat tekan pada paving block.

Untuk menentukan rumus dasar tekanan dan menetukan tekanan pada mesin dalam sistem hidrolik nya adalah

$$
\mathrm{P}=\frac{\mathrm{F}}{A}
$$

Dimana :

$$
\begin{aligned}
& \mathrm{P}=\operatorname{tekanan}\left(\mathrm{N} / \mathrm{m}^{2}\right) \\
& \mathrm{A}=\text { luas penampang }\left(\mathrm{m}^{2}\right) \\
& \mathrm{F}=\operatorname{gaya}(\mathrm{N})
\end{aligned}
$$

Komponen - Komponen Penyusun Sistem Hidrolik

- Motor

Motor berfungsi sebagai pengubah dari tenaga listrik menjadi tenaga mekanis. Dalam sistem hidrolik motor berfungsi sebagai penggerak utama dari semua komponen hidrolik dalam rangkaian ini. Kerja dari motor itu dengan cara memutar poros pompa yang dihubungkan dengan poros input motor. Motor yang digunakan adalah motor AC 2 HP 1 fasa.

- Pompa Hidrolik

Pompa hidrolik ini digerakkan secara mekanis oleh motor listrik. Pompa hidrolik berfungsi untuk mengubah energi mekanik menjadi energi hidrolik dengan cara menekan fluida hidrolik ke dalam sistem. Dalam sistem hidrolik, pompa merupakan suatu alat untuk menimbulkan atau membangkitkan aliran fluida (untuk memindahkan sejumlah volume fluida) dan untuk memberikan daya sebagaimana diperlukan. Apabila pompa digerakkan motor (penggerak utama), pada dasarnya pompa melakukan dua fungsi utama :

1. Pompa menciptakan kevakuman sebagian pada saluran masuk pompa. Vakum ini memungkinkan tekanan atmospher untuk mendorong fluida dari tangki (reservoir) ke dalam pompa.

2. Gerakan mekanik pompa menghisap fluida ke dalam rongga pemompaan, dan membawanya melalui pompa, kemudian mendorong dan menekannya ke dalam sistem hidrolik.

\section{- Katup (Valve)}

Dalam sistem hidrolik, katup berfungsi sebagai pengatur tekanan dan aliran fluida yang sampai ke silinder kerja

\section{- Silinder Kerja Hidrolik}

Silinder kerja hidrolik merupakan komponen utama yang berfungsi untuk merubah dan meneruskan daya dari tekanan fluida, dimana fluida akan mendesak piston yang merupakan satusatunya komponen yang ikut bergerak untuk melakukan gerak translasi yang kemudian gerak ini diteruskan ke bagian mesin melalui batang piston. Menurut kontruksi, silinder kerja hidrolik dibagi menjadi dua macam tipe dalam sistem hidrolik, antara lain :

1. Silinder kerja penggerak tunggal (single Acting)

Silinder kerja jenis ini hanya memiliki satu buah ruang fluida kerja didalamnya, yaitu ruang silinder di atas atau di bawah piston. Kondisi ini mengakibatkan silinder kerja hanya bisa melakukan satu buah gerakan, yaitu gerakan tekan. Sedangkan untuk kembali ke posisi semula, ujung batang piston didesak oleh gravitasi atau tenaga dari luar.

2. Silinder kerja penggerak ganda (double Acting) 
Silinder kerja ini merupakan silinder kerja yang memiliki dua buah ruang fluida didalam silinder yaitu ruang silinder di atas piston dan di bawah piston, hanya saja ruang di atas piston ini lebih kecil bila dibandingkan dengan yang di bawah piston karena sebagian ruangnya tersita oleh batang piston. Dengan konstruksi tersebut silinder kerja memungkinkan untuk dapat melakukan gerakan bolakbalik atau maju-mundur.

\section{Metode Penelitian}

\section{Tempat penelitian}

Penelitian ini dilakukan di Laboratorium Terpadu Jurusan Teknik Mesin Fakultas Teknik Universitas Muhammadiyah Metro.

\section{Tahapan Pelaksanaan Penelitian}

Adapun metode yang digunakan dalam penelitian ini adalah metode eksperimental, dengan tahapan-tahapan penelitian adalah sebagai berikut :

\section{a) Tahap Persiapan}

Tahapan persiapan meliputi gambar desain alat pembuat paving blok dan penyediaan alat dan bahan untuk pembuatan alat tersebut dan penunjang kegiatan penelitian lainnyaa

\section{- Skema Alat}

Skema alat pembuat paving blok yang akan diuji seperti terlihat pada Gambar 3 dibawah ini.

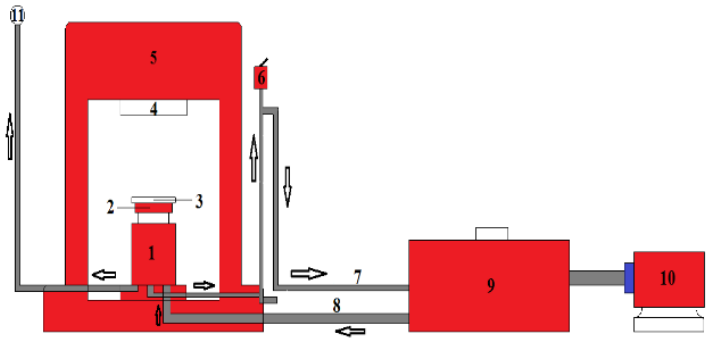

Gambar 3. Skema Alat Pembuat Paving Blok

Keterangan Gambar :

1. Hidrolik

2. Plat penyangga cetakan

3. Cetakan paving block

4. Plat penahan cetakan

5. Rangka mesin pencetak paving block

6. Katup

7. Pipa aliran fluida output

8. Pipa aliran fluida input

9. Pompa fluida

10. Motor listrik

11. Pressure gauge

- Alat dan Bahan yang digunakan

Adapun alat dan bahan yang digunakan dalam pembuatan alat adalah sebagai berikut Mesin pencetak paving block, Mesin las, Mesin Gerinda, Mesin Bor, Meteran, Kunci soket, Baut, Cat besi, Pipa, Valve.

- Peralatan Penunjang Penelitian

Peralatan yang akan digunakan adalah sebagai berikut Motor Listrik, Pompa hidroulik dan Pressure gauge.

b) Tahap Pembuatan dan Pengujian

Pada tahap Pembuatan Paving Blok dilakukan adalah membuat paving blok dengan tekanan maksimum pada saat proses pengepresan yang dapat dihasilkan oleh alat pencetak paving blok, dengan langkah-langkah sebagai berikut :

1. Siapkan bahan yang akan digunakan untuk membuat benda uji seperti semen dan pasir dengan perbandingan 1:4. 
2. Campur bahan tersebut dan aduk secara bersama-sama sampai merata (homogen). Pencampuan dilakukan ditempat yang kedap air untuk mencegah air semen merembes keluar.

3. Mengaduk bahan biasanya dilakukan dengan tangan untuk jumlah yang kecil atau dengan mesin pengaduk (mixer) untuk jumlah yang besar.

4. Isi cetakan dengan adukan yang sudah disediakan.

5. Setelah itu meratakan permukaan cetakan dari adukan berlebih, kemudian di press dengan menggunakan mesin pencetak paving block.

6. Spesimen uji kemudian di keluarkan dari cetakan dan diletakan di atas papan dan dikeringkan pada suhu udara kamar selama \pm 24 jam.

7. Kemudian rendam benda uji dalam bak perendam \pm 48 jam.

8. Keringkan benda uji sampai umur uji untuk uji tekan dan siap pakai kemudian dilakukan pengujian.

Untuk pengujian mutu tekan beton paving blok, menggunakan standar yang diatur dalam SNI 03-0691-1996. Dalam uji kuat tekan digunakan masing-masing 3 buah benda uji dalam setiap variasi cetakan, dengan umur uji hingga 28 hari.

1. Siapkan benda uji yang akan diuji tekan.

2. Menentukan berat dan ukuran benda uji.

3. Meletakan benda uji pada mesin tekan secara sentris.

4. Atur posisi benda uji agar berada tepat ditengah alat uji.

5. Menjalankan mesin tekan dengan penambahan beban antara 2 sampai 4 $\mathrm{kg} / \mathrm{cm}^{2}$ per-detik.

6. Melakukan pembebanan sampai benda uji menjadi hancur.

7. Mencatat beban maksimum yang dapat ditahan benda uji.

8. Menggambar/mendokumentasikan bentuk kerusakan benda uji.

9. Menghitung kuat tekan beton, yaitu besarnya beban persatuan luas.
10. Selanjutnya ulangi data minimal $3 \mathrm{kali}$ pengulangan.

11. Bentuk benda uji berdasarkan SNI 030691-1996 sebagai berikut :

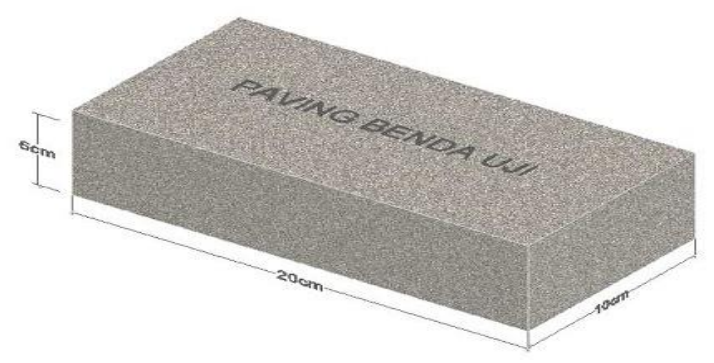

Gambar 4. Bentuk spesimen benda uji

c) Tahap Pengolahan data, Analisa data dan kesimpulan.

Setelah pengujian dilakukan, maka akan dilakukan pengolahan data dan analisa dari hasil pengujian. Dari hasil analisa maka akan ditarik kesimpulan yang merupakan hasil akhir penelitian dan harus sesuai dengan tujuan dari penelitian.

\section{Diagram Alir Penelitian}

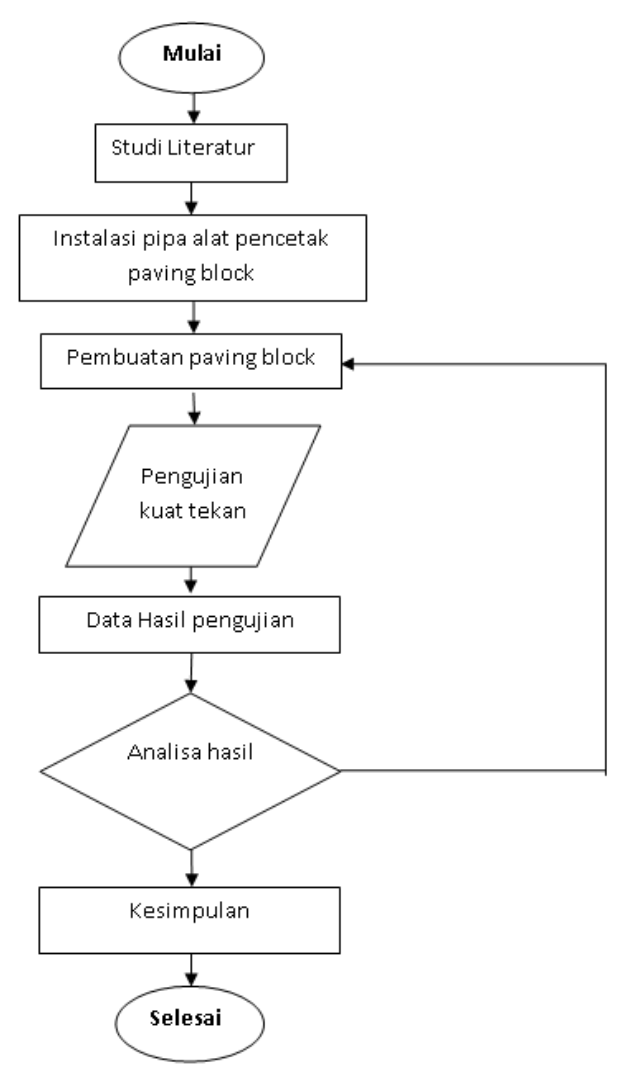

Gambar 5. Diagram Alir Penelitian 


\section{Hasil Dan Pembahasan}

\section{Hasil Pengepressan Paving Block}

Penelitian dilakukan menggunakan 3 jenis cetakan dengan bahan baku plat baja karbon rendah dengan spesifikasi sebagai berikut :

1. Variasi 2 cetakan dengan ukuran Panjang $\mathrm{x}$ Lebar $=21,2 \mathrm{~cm} \times 21,8 \mathrm{~cm}=$ $462,16 \mathrm{~cm}^{2}$

2. Variasi 3 cetakan dengan ukuran Panjang $\times$ Lebar $=32 \mathrm{~cm} \times 20,10 \mathrm{~cm}=$ $643,2 \mathrm{~cm}^{2}$

3. Variasi 4 cetakan dengan ukuran Panjang $\times$ Lebar $=41,5 \mathrm{~cm} \times 21,5 \mathrm{~cm}=$ $892,25 \mathrm{~cm}^{2}$

Data - data ini sebelumnya diambil dengan menggunakan alat press hidrolik dan alat uji tekan, adapun hasil pengepressan dan pengujian kuat tekan tersebut aplikasinya dapat di sajikan pada tabel berikut :

Tabel 3. Tekanan pada saat pengepressan variasi 2 cetakan

\begin{tabular}{|c|c|c|c|}
\hline Pengujian & Cetakan & $\begin{array}{c}\text { Tekanan } \\
\text { Pengepresan } \\
\left(\mathrm{kg} / \mathrm{cm}^{2}\right)\end{array}$ & $\begin{array}{c}\text { Luas } \\
\text { Penampang } \\
\text { Cetakan } \\
\left(\mathrm{cm}^{2}\right)\end{array}$ \\
\hline \multirow{2}{*}{1} & $\mathrm{~A}$ & 13 & 462,16 \\
\cline { 2 - 2 } & $\mathrm{B}$ & 13 & 462,16 \\
\hline \multirow{2}{*}{2} & $\mathrm{~A}$ & \multirow{2}{*}{$\mathrm{B}$} & 462,16 \\
\cline { 2 - 2 } 3 & $\mathrm{~B}$ & 13 & 462 \\
\cline { 2 - 2 } & $\mathrm{A}$ & & \multirow{2}{*}{$\mathrm{B}$} \\
\hline
\end{tabular}

Tabel 4. Tekanan pada saat pengepressan variasi 3 cetakan

\begin{tabular}{|c|c|c|c|}
\hline Pengujian & Cetakan & $\begin{array}{c}\text { Tekanan } \\
\text { Pengepresan } \\
\left(\mathrm{kg} / \mathrm{cm}^{2}\right)\end{array}$ & $\begin{array}{c}\text { Luas } \\
\text { Penampang } \\
\text { Cetakan } \\
\left(\mathrm{cm}^{2}\right)\end{array}$ \\
\hline \multirow{3}{*}{1} & A & \multirow{3}{*}{13} & \multirow{3}{*}{643,2} \\
\hline & $\mathrm{B}$ & & \\
\hline & $\mathrm{C}$ & & \\
\hline \multirow{3}{*}{2} & A & \multirow{3}{*}{13} & \multirow{3}{*}{643,2} \\
\hline & B & & \\
\hline & $\mathrm{C}$ & & \\
\hline \multirow{3}{*}{3} & A & \multirow{3}{*}{13} & \multirow{3}{*}{643,2} \\
\hline & B & & \\
\hline & $\mathrm{C}$ & & \\
\hline
\end{tabular}

Tabel 5. Tekanan pada saat pengepressan variasi 4 cetakan

\begin{tabular}{|c|c|c|c|}
\hline Pengujian & Cetakan & $\begin{array}{c}\text { Tekanan } \\
\text { Pengepresan } \\
\left(\mathrm{kg} / \mathrm{cm}^{2}\right)\end{array}$ & $\begin{array}{c}\text { Luas } \\
\text { Penampang } \\
\text { Cetakan } \\
\left(\mathrm{cm}^{2}\right)\end{array}$ \\
\hline \multirow{4}{*}{1} & A & \multirow{4}{*}{13} & \multirow{4}{*}{892,25} \\
\hline & B & & \\
\hline & $\mathrm{C}$ & & \\
\hline & $\mathrm{D}$ & & \\
\hline \multirow{4}{*}{2} & A & \multirow{4}{*}{13} & \multirow{4}{*}{892,25} \\
\hline & B & & \\
\hline & $\mathrm{C}$ & & \\
\hline & $\mathrm{D}$ & & \\
\hline \multirow{4}{*}{3} & A & \multirow{4}{*}{13} & \multirow{4}{*}{892,25} \\
\hline & B & & \\
\hline & $\mathrm{C}$ & & \\
\hline & $\mathrm{D}$ & & \\
\hline
\end{tabular}

Data - data tersebut diambil dengan menggunakan alat presure geuge pada alat tekan press paving block dengan pengambilan data untuk masing-masing variasi cetakan.

Tabel 6. Hasil Uji Kuat Tekan dengan variasi 2 Cetakan

\begin{tabular}{|c|c|c|c|c|}
\hline Pengujian & Cetakan & Berat & $\begin{array}{c}\text { Gaya } \\
\text { Tekanan } \\
(\mathrm{kg})\end{array}$ & $\begin{array}{c}\text { Luas Penampang } \\
\text { Bidang Tekan } \\
\left(\mathrm{mm}^{2}\right)\end{array}$ \\
\hline \multirow{2}{*}{1} & $\mathrm{~A}$ & 2,3 & 165000 & 20000 \\
\cline { 2 - 5 } & $\mathrm{B}$ & 2,3 & 170000 & 20000 \\
\hline \multirow{2}{*}{2} & $\mathrm{~A}$ & 2,3 & 170000 & 20000 \\
\cline { 2 - 5 } & $\mathrm{B}$ & 2,3 & 175000 & 20000 \\
\hline \multirow{2}{*}{3} & $\mathrm{~A}$ & 2,2 & 160000 & 20000 \\
\cline { 2 - 5 } & $\mathrm{B}$ & 2,3 & 165000 & 20000 \\
\hline
\end{tabular}

Tabel 6. Hasil Uji Kuat Tekan dengan variasi 3 Cetakan

\begin{tabular}{|c|c|c|c|c|}
\hline Pengujian & Cetakan & Berat & $\begin{array}{c}\text { Gaya } \\
\text { Tekanan } \\
(\mathrm{kg})\end{array}$ & $\begin{array}{c}\text { Luas Penampang } \\
\text { Bidang Tekan } \\
\left(\mathrm{mm}^{2}\right)\end{array}$ \\
\hline \multirow{3}{*}{1} & A & 2,2 & 150000 & 20000 \\
\cline { 2 - 5 } & B & 2,2 & 160000 & 20000 \\
\cline { 2 - 5 } & C & 2,2 & 155000 & 20000 \\
\hline \multirow{2}{*}{2} & A & 2,2 & 140000 & 20000 \\
\cline { 2 - 5 } & B & 2,2 & 150000 & 20000 \\
\cline { 2 - 5 } & C & 2,3 & 160000 & 20000 \\
\hline \multirow{3}{*}{3} & A & 2,2 & 150000 & 20000 \\
\cline { 2 - 5 } & B & 2,3 & 150000 & 20000 \\
\cline { 2 - 5 } & C & 2,2 & 140000 & 20000 \\
\hline
\end{tabular}


Tabel 7. Hasil Uji Kuat Tekan dengan variasi 4 Cetakan

\begin{tabular}{|c|c|c|c|c|}
\hline Pengujian & Cetakan & Berat & $\begin{array}{c}\text { Gaya } \\
\text { Tekanan } \\
(\mathrm{kg})\end{array}$ & $\begin{array}{c}\text { Luas Penampang } \\
\text { Bidang Tekan } \\
\left(\mathrm{mm}^{2}\right)\end{array}$ \\
\hline \multirow{4}{*}{1} & $\mathrm{~A}$ & 2,2 & 120000 & 20000 \\
\cline { 2 - 5 } & $\mathrm{B}$ & 2,1 & 100000 & 20000 \\
\cline { 2 - 5 } & $\mathrm{C}$ & 2,1 & 100000 & 20000 \\
\cline { 2 - 5 } & $\mathrm{D}$ & 2,1 & 95000 & 20000 \\
\hline \multirow{4}{*}{2} & $\mathrm{~A}$ & 2,2 & 100000 & 20000 \\
\cline { 2 - 5 } & $\mathrm{B}$ & 2,1 & 95000 & 20000 \\
\cline { 2 - 5 } & $\mathrm{C}$ & 2,2 & 120000 & 20000 \\
\cline { 2 - 5 } & $\mathrm{D}$ & 2,1 & 95000 & 20000 \\
\hline \multirow{3}{*}{3} & $\mathrm{~A}$ & 2,1 & 100000 & 20000 \\
\cline { 2 - 5 } & $\mathrm{B}$ & 2,2 & 110000 & 20000 \\
\cline { 2 - 5 } & $\mathrm{C}$ & 2,1 & 95000 & 20000 \\
\cline { 2 - 5 } & $\mathrm{D}$ & 2,1 & 95000 & 20000 \\
\hline
\end{tabular}

\section{Bahan Cetakan Paving Block}

Plat yang digunakan dalam pembuatan cetakan paving tersebut menggunakan bahan baja karbon rendah (mild steel) yang mengandung karbon antara $0,008 \%-0,3 \%$ C. Setiap satu ton baja karbon rendah mengandung 10-30 kg karbon. Baja karbon ini dalam perdangangan dibuat dalam bentuk platplat baja, baja strip dan baja batang atau progil. Berdasarkan jumlah karbon yang terkandung dalam baja, untuk membuat cetakan paving block menggunakan baja ST37 atau baja karbon rendah (mild steel) yang mempunyai kekuatan tarik sebesar 37 $\mathrm{kg} / \mathrm{mm}^{2}$.

\section{Perhitungan Gaya Saat Penekanan Pada Cetakan Paving Block}

Gaya yang terjadi pada cetakan paving block akibat penekanan oleh hidrolik, dapat dilihat dari hasil perhitungan sebagai berikut :

$$
\begin{aligned}
& \text { Variasi } 2 \text { cetakan } \\
& \text { Dik : } \mathrm{P}=13 \mathrm{~kg} / \mathrm{cm}^{2}=1275300 \mathrm{~N} / \mathrm{m}^{2} \\
& \qquad A_{b}=462,16 \mathrm{~cm}^{2}=0,046 \mathrm{~m}^{2} \\
& \begin{aligned}
\mathrm{F}= & \mathrm{P} \cdot \mathrm{A}_{\mathrm{b}} \\
= & 1275300 \mathrm{~N} / \mathrm{m}^{2} .0,046 \mathrm{~m}^{2} \\
= & 58663.8 \mathrm{~N}
\end{aligned}
\end{aligned}
$$

Jadi untuk mencari gaya tekan per cetakan dari variasi 2 cetakan dicari dengan rumus:

$$
\begin{aligned}
\tau & =\frac{F}{2} \\
& =\frac{58663.8 \mathrm{~N}}{2}=29331,9 \mathrm{~N}
\end{aligned}
$$

\section{Variasi 3 cetakan}

$$
\begin{aligned}
& \text { Dik : } \mathrm{P}=13 \mathrm{~kg} / \mathrm{cm}^{2}=1275300 \mathrm{~N} / \mathrm{m}^{2} \\
& \quad A_{b}=643.2 \mathrm{~cm}^{2}=0,064 \mathrm{~m}^{2} \\
& \begin{aligned}
\mathrm{F}= & \mathrm{P} \cdot \mathrm{A}_{\mathrm{b}} \\
= & 1275300 \mathrm{~N} / \mathrm{m}^{2} \cdot 0,064 \mathrm{~m}^{2} \\
= & 81619,2 \mathrm{~N}
\end{aligned}
\end{aligned}
$$

Jadi untuk mencari gaya tekan per cetakan dari variasi 3 cetakan dicari dengan rumus:

$$
\begin{aligned}
\tau & =\frac{F}{3} \\
& =\frac{81619,2 \mathrm{~N}}{3}=27206,4 \mathrm{~N}
\end{aligned}
$$

Variasi 4 cetakan

$$
\begin{aligned}
& \text { Dik: } \mathrm{P}=13 \mathrm{~kg} / \mathrm{cm}^{2}=1275300 \mathrm{~N} / \mathrm{m}^{2} \\
& A_{b}=892,25 \mathrm{~cm}^{2}=0,089 \mathrm{~m}^{2} \\
& \mathrm{~F}=\mathrm{P} \cdot \mathrm{A}_{\mathrm{b}} \\
& =1275300 \mathrm{~N} / \mathrm{m}^{2} \cdot 0,089 \mathrm{~m}^{2} \\
& =113501,7 \mathrm{~N}
\end{aligned}
$$

Jadi untuk mencari gaya tekan per cetakan dari variasi 4 cetakan dicari dengan rumus:

$$
\begin{aligned}
\tau & =\frac{F}{4} \\
& =\frac{113501,7 \mathrm{~N}}{4}=28375,425 \mathrm{~N}
\end{aligned}
$$

\section{Perhitungan Tegangan Lentur pada cetakan paving yang di Izinkan}

$$
\begin{aligned}
\tau_{i} & =\frac{\sigma_{t}}{s f_{1} s f_{2}} \\
\sigma_{t} & =37 \mathrm{~kg} / \mathrm{mm}^{2}=362970000 \mathrm{~N} / \mathrm{m}^{2} \\
s f_{1} & =\text { faktor keamanan } 6,0 \\
s f_{2} & =\text { faktor keamanan } 2,0 \\
& =\frac{362970000 \mathrm{~N} / \mathrm{m}^{2}}{6,0.2,0} \\
& =\frac{362970000 \mathrm{~N} / \mathrm{m}^{2}}{12} \\
& =30247500 \mathrm{~N} / \mathrm{m}^{2}
\end{aligned}
$$




\section{Perhitungan Tegangan Lentur pada cetakan paving yang Terjadi}

\section{Variasi 2 cetakan}

a) $\tau_{\mathrm{t} 21}=\frac{F}{A}$

Dik: Panjang plat $(P)=200 \mathrm{~mm}=0,2 \mathrm{~m}$

Tebal plat $(\mathrm{T})=0,06 \mathrm{~m}$

$$
\begin{aligned}
\mathrm{A} & =\mathrm{P} . \mathrm{T}=0,2 \mathrm{~m} \times 0,06 \mathrm{~m} \\
& =0,012 \mathrm{~m}^{2} \times 3 \text { batang plat } \\
& =0,036 \mathrm{~m}^{2} \\
\tau_{\mathrm{t} 21} & =\frac{58663,8 \mathrm{~N}}{0,036 \mathrm{~m}^{2}} \\
& =1629550 \mathrm{~N} / \mathrm{m}^{2}
\end{aligned}
$$

b) $\tau_{\mathrm{t} 22}=\frac{F}{A}$

Dik: Lebar plat $(\mathrm{L})=100 \mathrm{~mm}=0,1 \mathrm{~m}$

Tebal plat $(\mathrm{T})=0,06 \mathrm{~m}$

$$
\begin{aligned}
\mathrm{A} & =\mathrm{L} . \mathrm{T}=0,1 \mathrm{~m} \times 0,06 \mathrm{~m} \\
& =0,006 \mathrm{~m}^{2} \times 4 \text { batang plat } \\
& =0,024 \mathrm{~m}^{2} \\
\tau_{\mathrm{t} 22} & =\frac{58663,8 \mathrm{~N}}{0,024 \mathrm{~m}^{2}} \\
& =2444325 \mathrm{~N} / \mathrm{m}^{2}
\end{aligned}
$$

\section{Variasi 3 cetakan}

a) $\tau_{\mathrm{t} 31}=\frac{F}{A}$

Dik: Panjang plat $(\mathrm{P})=200 \mathrm{~mm}=0,2 \mathrm{~m}$

Tebal plat $(\mathrm{T})=0,05 \mathrm{~m}$

$\mathrm{A}=\mathrm{P} . \mathrm{T}=0,2 \mathrm{~m} \times 0,05 \mathrm{~m}$

$=0,01 \mathrm{~m}^{2} \times 4$ batang plat

$$
=0,04 \mathrm{~m}^{2}
$$

$$
\begin{aligned}
\tau_{\mathrm{t} 31} & =\frac{81619,2 \mathrm{~N}}{0,04 \mathrm{~m}^{2}} \\
& =2040480 \mathrm{~N} / \mathrm{m}^{2}
\end{aligned}
$$

b) $\tau_{\mathrm{t} 32}=\frac{F}{A}$

Dik: Lebar plat $(\mathrm{L})=100 \mathrm{~mm}=0,1 \mathrm{~m}$

Tebal plat $(\mathrm{T})=0,05 \mathrm{~m}$

$\mathrm{A}=\mathrm{L} . \mathrm{T}=0,1 \mathrm{~m} \times 0,05 \mathrm{~m}$

$=0,005 \mathrm{~m}^{2} \times 6$ batang plat

$$
=0,03 \mathrm{~m}^{2}
$$

$$
\begin{aligned}
\tau_{\mathrm{t} 32} & =\frac{81619,2 \mathrm{~N}}{0,03 \mathrm{~m}^{2}} \\
& =2720640 \mathrm{~N} / \mathrm{m}^{2}
\end{aligned}
$$

\section{Variasi 4 cetakan}

a) $\tau_{\mathrm{t} 41}=\frac{F}{A}$

Dik: Panjang plat $(\mathrm{P})=200 \mathrm{~mm}$

$$
=0,2 \mathrm{~m}
$$

Tebal plat $(\mathrm{T})=0,05 \mathrm{~m}$

$$
\mathrm{A}=\mathrm{P} . \mathrm{T}=0,2 \mathrm{~m} \times 0,05 \mathrm{~m}
$$

$=0,01 \mathrm{~m}^{2} \times 6$ batang plat

$$
=0,06 \mathrm{~m}^{2}
$$

$$
\begin{aligned}
\tau_{\mathrm{t} 41} & =\frac{113501,7 \mathrm{~N}}{0,06 \mathrm{~m}^{2}} \\
& =1891695 \mathrm{~N} / \mathrm{m}^{2}
\end{aligned}
$$

b) $\tau_{\mathrm{t} 42}=\frac{F}{A}$

Dik: Lebar plat $(\mathrm{L})=100 \mathrm{~mm}=0,1 \mathrm{~m}$

Tebal plat $(\mathrm{T})=0,5 \mathrm{~m}$

$$
\begin{aligned}
& \mathrm{A}=\mathrm{L} \cdot \mathrm{T}=0,1 \mathrm{~m} \times 0,05 \mathrm{~m} \\
& =0,005 \mathrm{~m}^{2} \times 6 \text { batang plat } \\
& =0,03 \mathrm{~m}^{2} \\
& \tau_{\mathrm{t} 42}=\frac{113501,7 \mathrm{~N}}{0,03 \mathrm{~m}^{2}}
\end{aligned}
$$$$
=3783390 \mathrm{~N} / \mathrm{m}^{2}
$$

6. Hasil Perhitungan Uji Kuat Tekan dengan variasi 2 Cetakan

\section{Pengujian 1}

a. $\tau 1=\frac{F}{A}$

Dik: $\mathrm{F}=165 \mathrm{KN}=165000 \mathrm{~N}$

$$
\begin{aligned}
& =\frac{165000 \mathrm{~N}}{20000 \mathrm{~mm}^{2}} \\
& =8,25 \mathrm{~N} / \mathrm{mm}^{2} \\
& =8250000 \mathrm{~N} / \mathrm{m}^{2} \\
& =8250 \mathrm{KPa}
\end{aligned}
$$

Sehingga : $\tau 1=8,25 \mathrm{MPa}$ 
b. $\tau 2=\frac{F}{A}$

Dik: $\mathrm{F}=170 \mathrm{KN}=170000 \mathrm{~N}$

$$
\begin{aligned}
= & \frac{170000 \mathrm{~N}}{20000 \mathrm{~mm}^{2}} \\
= & 8,5 \mathrm{~N} / \mathrm{mm}^{2} \\
= & 8500000 \mathrm{~N} / \mathrm{m}^{2} \\
= & 8500 \mathrm{KPa} \\
& \tau 2=8,5 \mathrm{MPa} \\
\text { Rata }- \text { rata }= & 8,25 \mathrm{MPa}+8,5 \mathrm{Mpa} \\
= & \frac{16,75 \mathrm{MPa}}{2}=8,375 \mathrm{MPa}
\end{aligned}
$$

\section{Pengujian 2}

A. $\tau 1=\frac{F}{A}$

Dik: $\mathrm{F}=170 \mathrm{KN}=170000 \mathrm{~N}$

$$
\begin{aligned}
& =\frac{170000 \mathrm{~N}}{20000 \mathrm{~mm}^{2}} \\
& =8,5 \mathrm{~N} / \mathrm{mm}^{2} \\
& =8500000 \mathrm{~N} / \mathrm{m}^{2} \\
& =8500 \mathrm{KPa} \\
& \tau=8,5 \mathrm{MPa} \\
& \text { B. } \tau 2=\frac{F}{A}
\end{aligned}
$$

Dik: $\mathrm{F}=175 \mathrm{KN}=175000 \mathrm{~N}$

$$
\begin{aligned}
= & \frac{175000 \mathrm{~N}}{20000 \mathrm{~mm}^{2}} \\
= & 8,75 \mathrm{~N} / \mathrm{mm}^{2} \\
= & 8750000 \mathrm{~N} / \mathrm{m}^{2} \\
& =8750 \mathrm{KPa} \\
\tau & =8,75 \mathrm{MPa}
\end{aligned}
$$

$$
\begin{aligned}
\text { Rata }- \text { rata } & =8,5 \mathrm{MPa}+8,75 \mathrm{MPa} \\
& =\frac{17,25 \mathrm{MPa}}{2}=8,625 \mathrm{MPa}
\end{aligned}
$$

\section{Pengujian 3}

a. $\tau 1=\frac{F}{A}$

Dik: $F=160 \mathrm{KN}=160000 \mathrm{~N}$

$$
\begin{aligned}
& =\frac{160000 \mathrm{~N}}{20000 \mathrm{~mm}^{2}} \\
& =8 \mathrm{~N} / \mathrm{mm}^{2}
\end{aligned}
$$

$$
\begin{aligned}
& =8000000 \mathrm{~N} / \mathrm{m}^{2} \\
& =8000 \mathrm{KPa} \\
& \tau=8 \mathrm{MPa}
\end{aligned}
$$

b. $\tau 2=\frac{F}{A}$

Dik: $\mathrm{F}=165 \mathrm{KN}=165000 \mathrm{~N}$

$$
\begin{gathered}
=\frac{165000 \mathrm{~N}}{20000 \mathrm{~mm}^{2}} \\
=8,25 \mathrm{~N} / \mathrm{mm}^{2} \\
=8250000 \mathrm{~N} / \mathrm{m}^{2} \\
=8250 \mathrm{KPa} \\
\tau=8,25 \mathrm{MPa} \\
\text { Rata }- \text { rata }=8 \mathrm{MPa}+8,25 \mathrm{MPa} \\
=\frac{16,25 \mathrm{MPa}}{2}=8,125 \mathrm{MPa}
\end{gathered}
$$

Sehingga didapat :

Total rata-rata $=\frac{8,375 M P a+8,625 M P a+8,125 M P a}{3}$

$$
=8,375 \mathrm{MPa}
$$

Dengan perhitungan seperti diatas maka akan didapat hasil perhitungan Uji Kuat Tekan dengan variasi 2, 3 dan 4 Cetakan seperti dalam Tabel 8. diabawah ini

Tabel 8. Hasil total rata-rata kuat tekan dari variasi 2,3, daan 4 cetakan

\begin{tabular}{|c|c|}
\hline $\begin{array}{c}\text { Variasi Jumlah } \\
\text { Cetakan }\end{array}$ & $\begin{array}{c}\text { Total Rata-Rata } \\
\text { Kuat Tekan (MPa) }\end{array}$ \\
\hline 2 & 8,375 \\
\hline 3 & 7,527 \\
\hline 4 & 5,1041667 \\
\hline
\end{tabular}


Dari tabel diatas diperoleh hasil rata-rata dari uji kuat tekan, adapun penyajiannya dibuat dalam bentuk diagram batang seperti berikut.

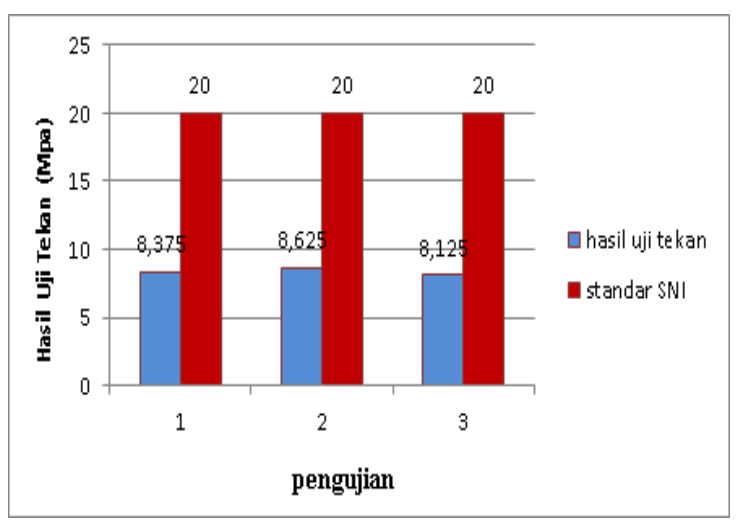

Gambar 6. Diagram hasil uji tekan paving block dengan variasi 2 cetakan

Pada diagram diatas menggambarkan hasil uji kuat tekan paving block untuk variasi 2 cetakan dalam satu kali pengepresan, adapun hasil yang didapat untuk cetakan pertama sebesar 8,375 $\mathrm{MPa}$, sedangkan untuk cetakan kedua didapat $8,625 \mathrm{MPa}$ dan untuk cetakan ketiga didapat 8,125 $\mathrm{MPa}$.

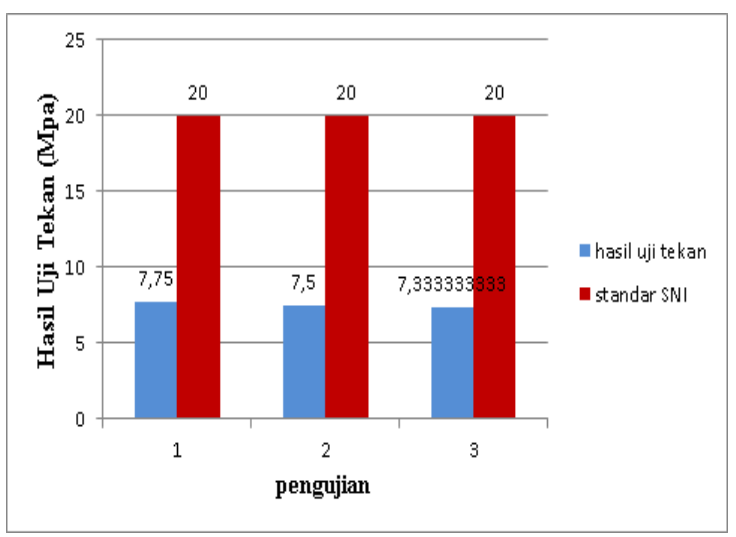

Gambar 7. Diagram hasil uji tekan paving block dengan variasi 3 cetakan

Pada diagram diatas menggambarkan hasil uji kuat tekan paving block untuk variasi 3 cetakan dalam satu kali pengepresan, adapun hasil yang didapat untuk cetakan pertama sebesar 7,75 $\mathrm{MPa}$, sedangkan untuk cetakan kedua didapat 7,5 MPa dan untuk cetakan ketiga didapat 7,33 $\mathrm{MPa}$.

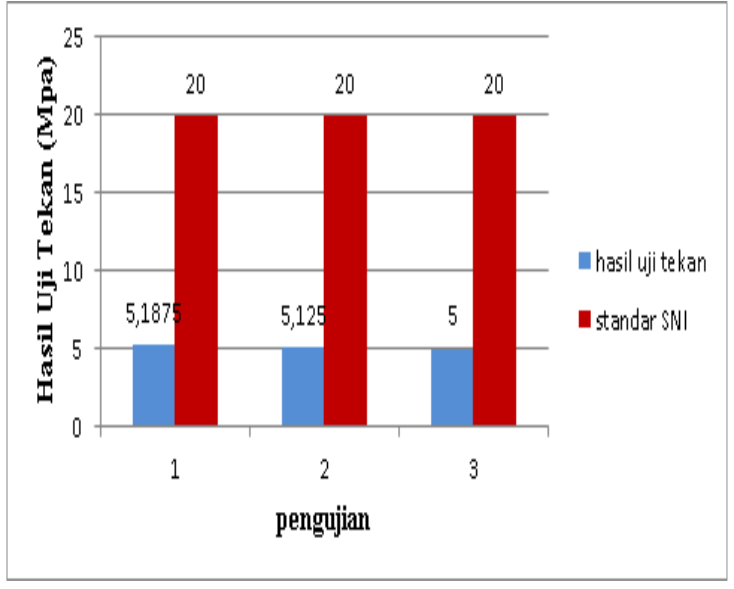

Gambar 8. Diagram hasil uji tekan paving block dengan variasi 4 cetakan

Pada diagram diatas menggambarkan hasil uji kuat tekan paving block untuk variasi 4 cetakan dalam satu kali pengepresan, adapun hasil yang didapat untuk cetakan pertama sebesar 5,1875 $\mathrm{MPa}$, sedangkan untuk cetakan kedua didapat 5,125 $\mathrm{MPa}$ dan untuk cetakan ketiga didapat $5 \mathrm{MPa}$.

\section{Pembahasan}

Gaya yang didapat pada cetakan paving block untuk variasi 2 cetakan sebesar 58663,8 $\mathrm{N}$, variasi 3 cetakan $81619,2 \mathrm{~N}$, dan variasi 4 cetakan 113501,7 N. Sehingga pada saat penekanan terjadi lenturan yang diakibatkan dari gaya penekanan pada saat pembuatan paving block. Adapun tegangan lentur yang terjadi pada saat penekanan didapat untuk variasi 2 cetakan sebesar $1629550 \mathrm{~N} / \mathrm{m}^{2}$ untuk panjang plat sedangkan untuk lebar sebesar $2444325 \mathrm{~N} / \mathrm{m}^{2}$, untuk variasi 3 cetakan sebesar $2040480 \mathrm{~N} / \mathrm{m}^{2}$ untuk panjang plat sedangkan untuk lebar sebesar $2720640 \mathrm{~N} / \mathrm{m}^{2}$, untuk variasi 4 cetakan sebesar $1891695 \mathrm{~N} / \mathrm{m}^{2}$ untuk panjang plat sedangkan untuk lebar sebesar $3783390 \mathrm{~N} / \mathrm{m}^{2}$.

Untuk kekuatan uji tekan didapat untuk variasi 2 cetakan didapat nilai ratarata pengujian 1 sebesar $8,375 \mathrm{MPa}$, pengujian 2 sebesar $8,625 \mathrm{MPa}$, dan pengujian 3 sebesar 8,125 $\mathrm{MPa}$. Untuk variasi 3 cetakan didapat nilai rata-rata pengujian 1 sebesar 7,75 $\mathrm{MPa}$, pengujian 2 
sebesar 7,5 $\mathrm{MPa}$, dan pengujian 3 sebesar 7,33 $\mathrm{MPa}$. Untuk variasi 4 cetakan didapat nilai rata-rata pengujian 1 sebesar 5,185 $\mathrm{MPa}$, pengujian 2 sebesar 5,125 $\mathrm{MPa}$, dan pengujian 3 sebesar $5 \mathrm{MPa}$. Sedangkan Hasil Uji Kuat Tekan Pada Setiap Variasi Cetakan yang berbeda didapatkan hasil total rata-rata sebagai berikut :

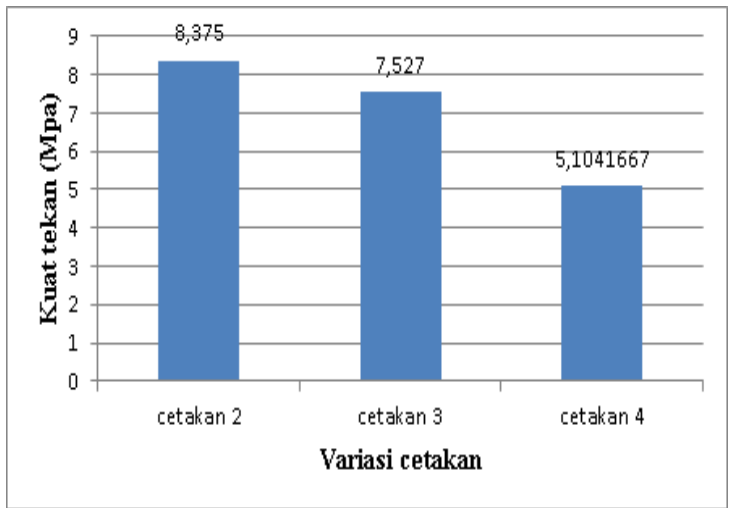

Gambar 9. Diagram perbandingan nilai rata-rata uji kuat tekan dari setiap variasi cetakan

Dari hasil perhitungan pengujian kuat tekan paving block didapatkan nilai rata-rata perbandingan untuk setiap variasi cetakan didapat 8,375 $\mathrm{MPa}$ untuk variasi 2 cetakan, 7,525 $\mathrm{MPa}$ untuk variasi 3 cetakan dan 5,1041667 MPa untuk variasi 4 cetakan. Bila melihat hasil rata-rata pada grafik diatas sesuai SNI nilai yang didapat utuk paving block pada variasi 2 cetakan termasuk dalam mutu untuk taman.

\section{Kesimpulan}

Dari penelitian yang telah dilakukan didapat kesimpulan sebagai berikut :

1. Dari hasil analisa sistem hidrolik pada pembuatan atau pengepresan paving block di dapat nilai $15 \mathrm{~kg} / \mathrm{cm}^{2}$ dengan gaya penekana yang terjadi pada hidrolik sebesar 11551,275 $\mathrm{N}$ dan gaya penekanan saat pembuatan atau pengeresan paving block sebesar 29430 $\mathrm{N}$ serta $13 \mathrm{~kg} / \mathrm{cm}^{2}$ dengan gaya penekana yang terjadi pada hidrolik sebesar 10011,105 N dan gaya penekanan saat pembuatan atau pengeresan paving block sebesar 25506 $\mathrm{N}$ dan dalam nilai rata-rata tekanan pengepresan $13,8 \mathrm{~kg} / \mathrm{cm}^{2}$ dengan gaya penekana yang terjadi pada hidrolik sebesar 10627,173 $\mathrm{N}$ dan gaya penekanan saat pembuatan atau pengeresan paving block sebesar $27075,6 \mathrm{~N}$

2. Dengan hasil pengujian kuat tekan pada paving block di dapat nilai rata-rata 8,3125 Mpa, karena hanya didapat nilai tersebut maka dikuat tekan paving block ini tidak termasuk kesemua mutu SNI dan kuat tekan tercapai minimal hanya pada sempel 2 dan 5 .

\section{Referensi}

[1] Sebayang Syukur, 2011. "Perbandingan Mutu Paving Block Produksi Manual Dengan Produksi Masinal'. Jurnal Rekayasa Vol. 15 No. 2, Agustus 2011. LAMPUNG: UNIVERSITAS LAMPUNG

[2] Adibroto,2014,Pengaruh Penambahan Berbagai Jenis Serat Pada Kuat Tekan Paving Block, TEKNIK SIPIL POLITEKNIK NEGERI, JURNAL REKAYASA SIPIL Padang.

[3] Moh. Dahlan, Budi Guanawan, Sugeng Slamet, 2013, Prototipe Mesin Press Otomatis Dengan Sistem Pneumatik Berbasis (PLC), Programmeble Logic Controller Untuk Produksi Paving Block Berstandar Nasional Indonesia (SNI) Dan Sistem Control Pada Mesin Paving Block Dan Pembuatan Nya. TEKNIK MESIN DAN TEKNIK ELEKTR,UNIVERSITAS MURIA,Kudus.

[4]Http://Www.Google.Co.Id/Prinsip+Kerj a+Alatpaving+Konvensional/, Download Tanggal 24 April 2015.

[5]Http://Www.Google.Co.Id/Prinsip+Kerj a+Alatpaving+Mekanis/, Download Tanggal 24 April 2015.

[6] Ariyadi, 2006, Pengembangan Mesin Tekan Bata Beton Untuk Lantai 
(Paving Block) Semi

Mekanis, Kandidat Peneliti Pertama, Laboratorium Beton B4T. Peneliti

Muda, B4T, Bandung 